\title{
Penyelenggaraan PAUD Berbasis Karakter Kebhinekaan sebagai Upaya Pencegahan Radikalisme Sejak Dini
}

\author{
Ahmad Yani ${ }^{\otimes_{1}}$, Jazariyah $^{2}$ \\ Pendidikan Islam Anak Usia Dini, Institut Agama Islam Negeri Syekh Nurjati Cirebon \\ DOI: $10.31004 /$ obsesi.v5i1.503
}

\begin{abstract}
Abstrak
Penelitian ini bertujuan untuk mengkaji upaya upaya lembaga dalam menangkal radikalisme pada anak usia dini. Metode penelitian yang digunakan dalam hal ini adalah penelitian kualitatif, dimana data data yang diperoleh dari hasil wawancara dan analisa lapangan dalam observasi serta catatan dokumentasi diolah secara deskriptif untuk menggambarkan kenyataan di lapangan. Hasil penelitian menunjukkan upaya pencegahan radikalisme dilakukan oleh kepala sekolah dan guru lembaga PAUD. Kepala sekolah melakukan upaya berupa perekrutan guru yang selektif. Dalam proses perekrutan terdapat aturan aturan yang harus ditaati. Pemilihan bahan ajar dilakukan pengawasan oleh kepala sekolah, sehingga bebas dari konten radikalisme. Upaya ini menyadarkan para pendidik bahwa ketidakhati hatian memilih buku ajar dapat berakibat fatal di kemudian hari. Pengenalan kebhinekaan melalui simulasi yang dilakukan oleh guru, serta sinergitas dengan orangtua anak didik dalam beberapa kegiatan seperti parenting. Guru berperan dalam mendidik karakter anak dengan karakter (teladan) dan membingkai kebhinekaan dalam bermain peran untuk anak usia dini. Hasil Penelitian ini menunjukkan bahwa simulasi bermain peran kebhinekaan dapat menjadi satu upaya pencegahan radikalisme.
\end{abstract}

Kata Kunci: radikalisme; kebhinekaa; anak usia dini.

\begin{abstract}
This research aims to assess the effort of PAUD in countering radicalism in early childhood. The methodology used in this case is qualitative study, where the data obtained from interviews and analized from observation field. Documentation record also used to describe the reality in the field. The result showed effort to prevent radicalism carried out by The headmaster and teachers. The headmaster made an effort by select teachers. There are some rules in teacher recruitment. The selection of the teaching material controlling by the school principal so that it can be free from radicalism. The effort to remind educators that carelessness in chosing teaching material will be fatal in future. The introduction of 'kebhinekaan' through a simulation done by by teachers, and synergy with parents students in several activities such as parenting. Teachers had a role in educating the character of a child with characters (role model) and enchase 'kebhinekaan' in a role playing to early childhood .This research result indicates that simulation of role-playing 'kebhinekaan' could be one efforts to prevent radicalism.
\end{abstract}

Keywords: radicalism; diversity; early childhood.

Copyright (c) 2020 Ahmad Yani, Jazariyah

$\triangle$ Corresponding author :

Email Address : kangyani75@gmail.com (Cirebon, Indonesia)

Received 18 March 2020, Accepted 19 April 2020, Published 20 April 2020 


\section{PENDAHULUAN}

Radikalisme saat ini menjadi isu yang masih diperhatikan secara serius oleh pemerintah, sehingga banyak lembaga pemerintahan melakukan aksi kegiatan pencegahan dengan berbagai upaya dan program tertentu. Diberitakan melalui cnnindonesia.com, pada tanggal 4 Nopember 2019 Menteri Pemberdayaan Aparatur Sipil Negara dan Reformasi Birokrasi (MenPANRB) Tjahjo Kumolo dalam pidatonya di hadapan ASN Provinsi Daerah Istimewa Yogyakarta, bahkan mengatakan bahwa akan disisipkan materi khusus dalam tes wawasan kebangsaan untuk pencegahan radikalisme pada perekrutan Calon Pegawai Negeri Sipil (CPNS) tahun 2019. Upaya ini sebagai bagian dari menjaga kebinekhaan yang menjadi fokus presiden Joko Widodo saat ini.

Bentuk kekhawatiran nyata pemerintah akan merebaknya radikalisme dan terorisme adalah terbentuknya Badan atau lembaga khusus untuk menangani terorisme. Pemerintah membentuk Badan Nasional Penanggulangan Terorisme (BNPT). Lembaga ini menyatakan bahwa radikalisme merupakan bibit lahirnya terorisme. Kasus terorisme yang tercatat dalam kurun waktu 2010-2017 yakni sekitar 130 kasus di Indonesia. Tingginya jumlah kasus tersebut mengindikasi perlunya penanganan serius yang dapat dimulai dari hal dasar, yakni memperhatikan kebutuhan anak-anak dan remaja untuk mendapatkan pendidikan kepribadian yang baik sejak dini sehingga bibit radikalisme negatif dapat dihindari (Abdillah, Muhammad, Ulya, Sodali, \& Choiriya, 2018)

Pelibatan aksi radikalisme saat ini mulai merambah pada anak-anak. Contoh kasus yang terjadi yakni serangan bom bunuh diri di tiga gereja di Surabaya pada hari Minggu, 13 Mei 2018. Pelaku bom bunuh diri adalah satu keluarga termasuk di dalamnya anak anak dalam keluarga tersebut. (national.kompas.com). Perilaku kekerasan yang dilakukan oleh anak tidak muncul secara tiba-tiba. Lingkungan baik keluarga, sekolah ataupun masyarakat berperan memberikan pengaruh dalam pembentukan karakter seorang anak.

Adanya doktrinasi kebencian terhadap suku, agama dan ras serta golongan lain yang dilakukan baik oleh orang tua, guru maupun masyarakat sekitar akan memberikan pengaruh buruk terhadap karakter anak. Sifat anak-anak yang mudah menyerap informasi tidak seharusnya diisi doktrin yang mengajarkan kekerasan dan radikalisme.

Konten yang berisikan paham negatif yang dapat merusak kebangsaan dan mengajak kekerasan nyatanya dijumpai dalam Lembar Kerja Siswa (LKS) pada buku paket pelajaran. Kejadian ini terjadi pada tahun 2015, dimana buku paket PAI yang disusun mengandung unsur intoleransi, dimana pada salah satu halamannya ada ajaran yang memperbolehkan membunuh kaum yang menyembah selain Allah atau orang yang dianggap musyrik (Umro, Stit, \& Pasuruan, 2017). Polemik ini menjadi satu kewaspadaan bersama bagi para pengelola lembaga pendidikan

Polemik lain bahkan muncul di tahun 2018, sebuah Taman Kanak-Kanak (TK) di Probolinggo, Jawa Timur mengadakan karnaval dimana murid murid TK dikenakan pakaian cadar dan memegang replika senjata. Fenomena inilah yang menjadi satu hal yang terus menimbulkan pertanyaan dan kekhawatiran tentang penanaman paham radikalisme pada anak usia dini (BBC News Indonesia, 2018). Simbol dalam berpakaian sesuai syariat seperti mengenakan cadar tidak mutlak mencirikan radikalisme, karena radikalisme adalah sebuah pemikiran yang tidak selalu dicirikan dengan penampilan.

Wahid Foundation bersama Lingkar survey pernah merilis hasil survey yang dilakukan bahwa pada tahun 2016 terdapat 11 juta dari 150 juta penduduk muslim Indonesia siap melakukan tindakan radikal. Nominal yang cukup tinggi karena mencapai 7,7 \% penduduk muslim Indonesia. Sementara itu, 600 ribu atau 0,4 persen penduduk muslim Indonesia pernah melakukan tindakan radikal (Wahid, 2017). Lebih mengejutkan lagi, Lestari (2016) menyebutkan bahwa anak- anak di sekolah tingkat dasar dan menengah bahkan taman kanak-kanak berisiko terpapar ajaran intoleransi dan radikalisme (Imron, 2018) 
Perkembangan dunia Pendidikan Anak Usia Dini sendiri memberikan keleluasaan bagi para pengusung gerakan radikal. Mudahnya pendirian lembaga, bagi para pengsung gerakan radikal menjadi celah untuk mengembangkan pahamnya, melalui lembaga pendidikan yang mereka bangun. Dengan melakukan pengembangan kurikulum sendiri, mulai dari tingkat Pendidikan Anak Usia Dini (PAUD), bahkan hingga pergduruan tinggi. Sebagai contoh dalam pembelajarannya mereka melarang anak-anak untuk bernyanyi apalagi lagu lagu kebangsaan yang menurutnya mengajarkan kemusyrikan. Para siswa bahkan tidak diperkankan untuk menggambar manusia atau binatang, sehingga merampas hak anak untuk mengembangkan kreativitas.(Khamid, 2016)

Kekerasan berupa sikap ekstrim dan radikal terjadi pada individu tidak begitu saja, terdapat proses penggemblengan dan doktrinasi yang membutuhkan proses. Perilaku ini muncul akibat adanya pengaruh atau pelatihan dari lingkungan pendidikan, yakni pendidikan dalam keluarga, sekolah ataupun masyarakat. Justin M Sihombing menyatakan bahwa sumber kekerasan dapat dilihat dari 3 aspek yakni biologis, psikologi dan lingkungan material (Sihombing, 2005). Perkembangan masyarakat dengan dunia yang serba open access saat ini mendorong sumber kekerasan dari lingkungan material yang patut diwaspadai.

Pemerolehan pengetahuan dengan mudah diakses. Anak usia dini yang saat ini sudah berkawan dengan gadget pun memiliki kemungkinan untuk dapat memperoleh content radikalisme secara mudah. Untuk itu upaya-upaya pencegahan harus dilakukan sedini mungkin sehingga dapat terhindarkan. Saat ini dalam hierarki pendidikan secara formal PAUD menduduki tingkatan paling dasar, sehingga menentukan pembentukan karakter anak ke depan.

Pendidikan anak usia dini (PAUD) dalam uraian Developmentally Appropriate Practices (DAP) dinyatakan sebagai pendidikan anak usia 0-8 tahun. Deskripsi lain menyebutkan bahwa PAUD adalah pemberian upaya untuk menstimulasi, membimbing, mengasuh dan pemberian kegiatan pembelajaran yang akan menghasilkan kemampuan dan ketrampilan pada anak (Nurfitriana, 2018).

Di Indonesia, pengertian anak usia dini lebih menunjuk pada rentang usia anak pra sekolah. Usia dimana anak belum memasuki Sekolah Dasar, sehingga umur prasekolah, yaitu usia 0-6 tahun, yakni merujuk pada UU NO. 20/2003 (Joni, 2015). Kegiatan pembelajaran PAUD diarahkan untuk mengembangkan 6 aspek perkembangan anak yakni aspek nilai agama dan moral, aspek kognitif, aspek seni, aspek bahasa, aspek sosial emosional dan aspek fisik motorik (Permendikbud No 137, 2014)

Proses penyelenggaran PAUD tidak dapat terlepas dari peran serta guru dalam pembelajaran, serta kepala sekolah sebagai pimpinan lembaga. Arah pengembangan lembaga dan pencapaiannya dikendalikan oleh seorang kepala sekolah. Pengembangan pencapaian aspek perkembangan anak usia dini yang dilakukan sekolah tidak dapat terlepas dari peran orangtua sebagai pendidik utama. Kepala sekolah memiliki peran dalam mensinergikan antara pola pendidikan yang dikembangkan di sekolah dengan di rumah melalui kegiatan pertemuan orang tua. Kerjasama antara tiga komponen ini dapat menciptakan keselarasan dalam pemerolehan perkembangan anak.

Lingkungan yang paling mendasar bagi anak adalah keluarga. Hubungan timbal balik terjadi dalam keluarga yakni hubungan antara orangtua dan anak, anak dengan anak lainnya (antar saudara)(Wahyudi \& Kurniasih, 2018). Peranan keluarga dalam hal ini dapat menjadi pendukung pencegahan radikalisme atau bisa jadi keluarga telah menanamkan benih benih radikalisme seperti pada kasus bom bunuh diri di Surabaya pada tahun 2018.

Ancaman radikalisme pada anak usia dini dapat bersumber baik dari keluarga, sekolah atau masyarakat. Karakter radikal muncul dari sebuah proses yang bisa jadi terselip dalam proses pendidikan yang diperoleh. Penyelenggaraan pendidikan dan lembaga pendidikan sangat berpeluang menjadi penyebar benih-benih radikalisme dan sekaligus deradikalisasi. Penelitian serta survey tentang radikalisme mensinyalir adanya lembaga 
pendidikan islam yang berkontribusi dalam mengajarkan radikalisme pada anak didik (Rokhmad, 2012).

Potensi radikalisme dapat dilihat dari radikal mind dan radikal attitude. Dari kedua tingkatan tersebut dapat digunakan sebagai cara menakar potensi radikalisme dari berbagai kalanganan masyarakat. Bentuk potensi radikalisme pada anak tentu sangat terkait dengan lingkungan tinggalnya dan lingkungan pendidikan yang dimiliki. Seperti, ucapan dan sikap yang berpotensi melahirkan kekerasan yang tidak sesuai dengan norma pendidikan sehingga menjadikan situasi pembelajaran yang tidak menyenangkan (Muchith, 2016)

Pekembangan kognitif anak usia dini belum mampu berpikir secara abstrak, anak anak lebih cenderung berpikir logis. Pada tingkatan berpikir seperti ini anak anak akan rentan terhadap pengaruh luar (Shobihah, 2018). Menurut Zahratul Mahmudat, Radikalisme memiliki empat karakteristik (Khoiriyah, 2019). Pertama, intoleran yakni tidak menghargai pendapat atau keyakinan orang lain. Kedua, sikap eksklusif, yakni sikap tertutup dan berusaha berbeda dengan kebiasaan orang banyak. Ketiga, sikap fanatik, yakni sikap yang selalu membenarkan diri sendiri dan menyalahkan orang lain. Keempat, sikap revolusioner, yakni kecenderungan untuk menggunakan kekerasan dalam mencapai tujuan.

Bentuk perilaku dan ucapan yang mengandung keempat unsurediatas dapat menjadi bentuk potensi radikalisme. Hal ini mengingat Kemampuan anak dalam mengolah informasi pada masa itu belum sempurna sehingga persepsi yang berbeda selalu dimungkinkan terjadi. Sementara itu pemahaman anak dari proses pembelajaran yang diterima di sekolah dan di luar sekolah akan menjadi landasan dalam berperilaku.

Adanya kenyataan di atas menjadi alasan bahwa paham radikalisme perlu dicegah sejak dini baik di lingkungan keluarga, sekolah maupun lingkungan masyarakat. Beberapa penelitian masih terfokus pada deradikalisasi dan belum menyentuh pada pendidikan anak usia dini, oleh karena itu perlu dilakukan penelitian bagaimana pencegahan radikalisme pada lembaga pendidikan anak usia dini. Penelitian ini ditujukan untuk menganalisa langkah langkah yang telah dilakukan lembaga pendidikan anak usia dini dalam upaya melakukan pencegahan radikalisme.

\section{METODOLOGI}

Penelitian ini bersifat deskriptif kualitatif, yang diarahkan untuk mendapatkan gambaran secara objektif tentang objek yang diteliti. Penelitian ini dibagi menjadi beberapa tahapan, yaitu: (1) Pra penelitian, yakni menyusun rancangan awal, pengurusan izin, penjajakan, pemilihan subjek dan informan, (2) tahap pelaksanaan penelitian di lapangan, yakni melakukan pengamatan (observasi) secara alamiah dan wajar, melakukan wawancara dengan informan serta mendokumentasikan data-data penelitian dan (3) pasca penelitian, dengan mengacu model interaktif bahwa analisis data tidak saja dilakukan setelah pengumpulan data, dimana selama tahap penarikan simpulan, peneliti selalu merujuk kepada suara dari lapangan untuk mendapatkan konfirmabilitas. Alur kegiatan penelitian dapat digambarkan sebagai berikut: 


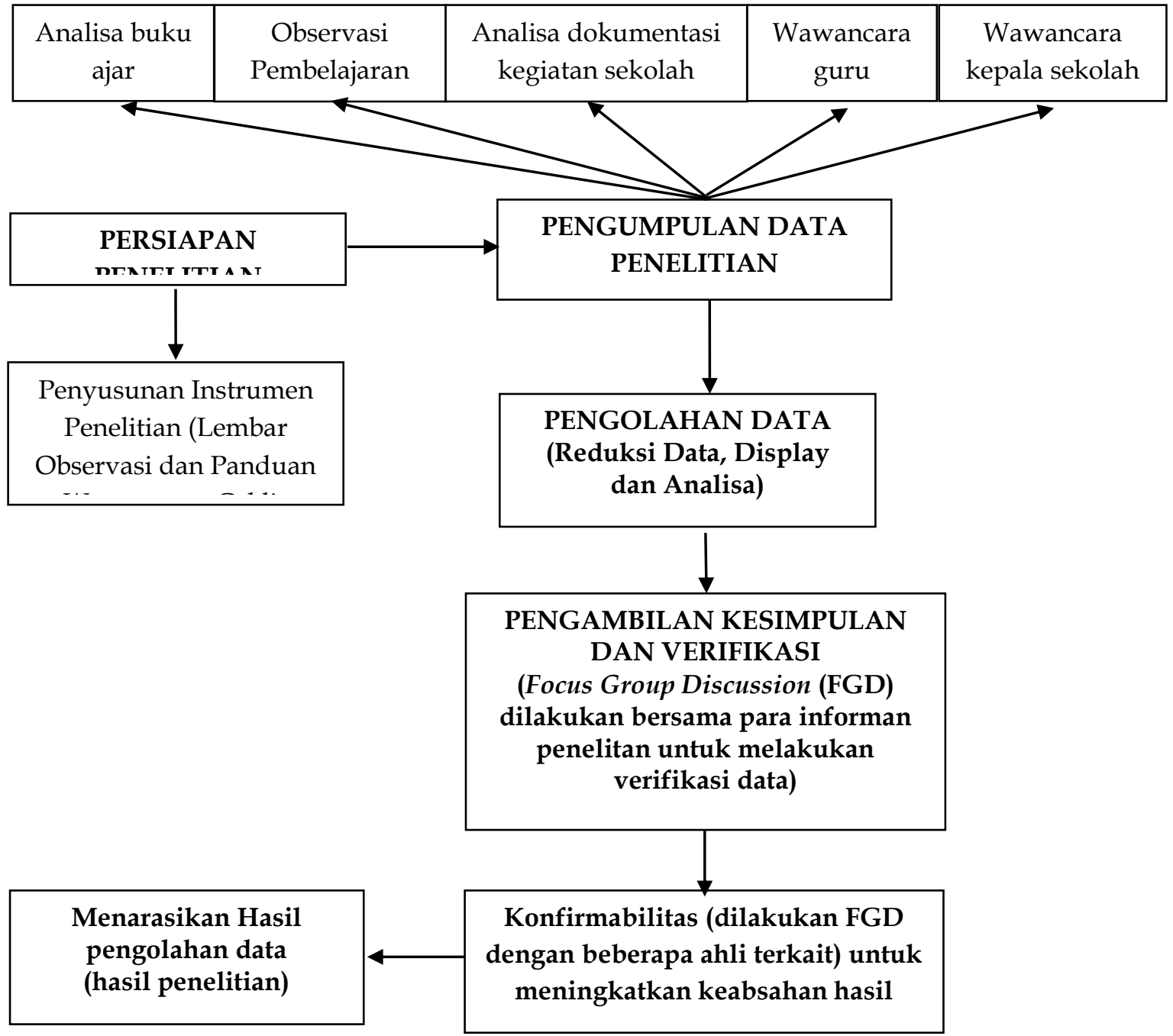

Gambar 1. Alur Pelaksanaan Penelitian

Subjek penelitian ini beberapa lembaga PAUD yang ada di wilayah kabupaten Cirebon, dengan mengacu pada purposive sampling maka diambil 5 lembaga yakni lembaga PAUD dibawah kementrian agama/ yayasan islam (RA). Instrumen yang digunakan dalam penelitian untuk pengumpulan data ini adalah: (1) petunjuk wawancara, (2) rekaman suara, (3) rekaman gambar, (4) dokumen-dokumen sekolah, (5) catatan lapangan yang tertulis, (6) lembar observasi lapangan.

\section{HASIL DAN PEMBAHASAN}

Proses pemerolehan data di lapangan menunjukkan beberapa hal terkait upayaupaya yang telah dilakukan oleh lembaga melalui kepala sekolah dan guru dalam hal ini. Kepala sekolah yang memiliki fungsi manajerial memiliki keleluasaan dalam penyelenggaraan PAUD baik dalam hal administratif maupun pengelolaan suasana akademik sekolah.

Lembaga yang dijadikan sampel pada penelitian ini berada dalam satu naungan kementrian yakni berupa Raudlatul Athfal (RA). Sekolah dengan lingkungan yang cenderung homogen dalam agama rentan akan adanya doktrinasi radikalisme, sehingga diharapkan muncul adanya upaya upaya yang dilakukan dalam hal pencegahan. Berdasarkan hasil wawancara dengan 5 kepala RA dengan beberapa RA diperoleh informasi bahwasanya hanya 1 lembaga yang pernah mengikutsertakan guru pada kegiatan seminar pencegahan radikalisme pada anak usia dini. Informasi ini bermanfaat sebagai pijakan awal 
seberapa besar pengetahuan kepala sekolah dan guru dalam hal radikalisme, yang akan mempengaruhi tindakan yang dilakukan dalam upaya pencegahan radikalisme.

Bersumber dari RA yang mengikutsertakan guru pada kegiatan seminar pencegahan radikalisme. Muncul pemahaman bahwa radikalisme tidak dapat dilihat dari penampilan, maka penampilan dengan simbolik keislaman sebagai contoh penggunaan niqob tidak dapat dikatakan sebagai bentuk radikalisme. Radikalisme lebih pada pemikiran dan sikap, sebagai contoh memberontak terhadap aturan dengan melakukan tindakan kekerasan.

Pernyataan tersebut membuktikan bahwa akar radikalisme terletak pada sifat agresi yang tumbuh dalam diri seseorang. Sikap agresi yang berlebihan akan memudahkan paham radikal masuk, sedangkan sikap agresi ini merupakan hasil bentukan lingkungan sekitar.(Alexandra, 2017).

\section{Proses Seleksi Guru}

Bentuk upaya manajerial kepala lembaga dalam hal ini kepala sekolah PAUD yang dapat berupa proses seleksi anggota-anggota lembaganya salah satunya guru. Hasil wawancara kepala sekolah lembaga yang dijadikan sampel menujukkan perbandingan yang cukup signifikan dalam hal proses perekrutan guru. 4 dari 5 sampel tidak melakukan proses perekrutan secara terstuktur melalui tes ataupun uji kualifikasi.

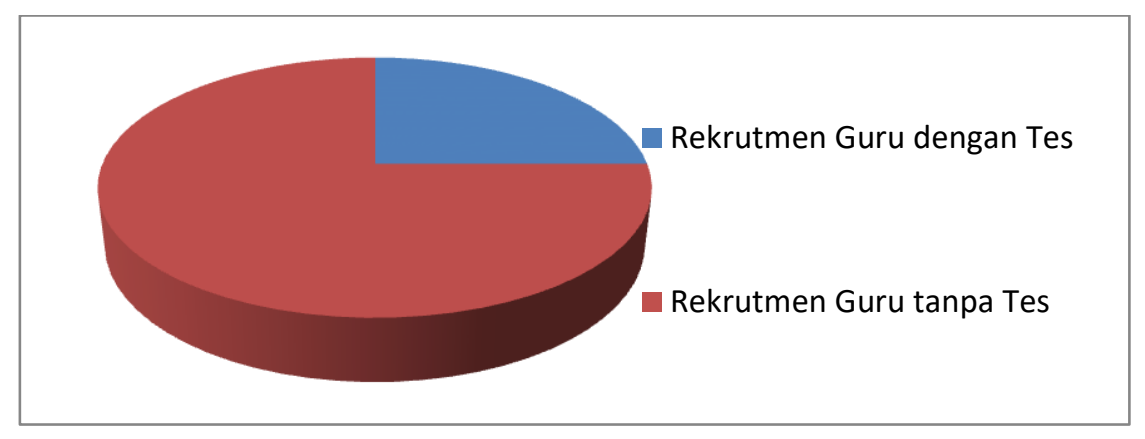

Gambar 2. Perbandingan Proses Perekrutan Guru PAUD

Beberapa kendala yang diungkap oleh Kepala Sekolah yang tidak melakukan proses seleksi dalam perekrutan guru terdiri dari empat hal. Pertama minat terhadap mengajar di PAUD masih rendah. kedua Ketersediaan lulusan yang sesuai kompetensi masih sedikit. Ketiga lembaga PAUD umumnya belum mampu memberikan imbalan kesejahteraan secara materi sehingga merasa sudah cukup beruntung apabila ada yang berniat mengajar di PAUD. Keempat umumnya pelamar guru PAUD masih dari kalangan sekitar yang cukup dipahami latar belakangnya.

Seleksi dalam perekrutan guru dengan memperhatikan identifikasi paparan radikalisme diyakini lembaga tersebut mampu menjadi gerbang awal pencegahan radikalisme pada anak usia dini. Lembaga yang tidak melakukan proses tes secara terstuktur bukan berarti tidak melakukan screening paparan radikalisme. Umumnya lembaga melakukan wawancara singkat dengan calon guru berupa pengalaman mengajak secara singkat dan kemampuan personal.

Tahapan selanjutnya untuk keberlangsungan sikap anti radikalisme adalah perlu diadakan pembinaan terhadap guru agar senantiasa memegang teguh islam sebagai agama yang cinta perdamaian. Beberapa lembaga juga setuju terhadap kegiatan workshop atau seminar pencegahan radikalisme. Lembaga ini berkomitmen akan mendelegasikan guru untuk mengikuti kegiatan tersebut jika ada yang menyelenggarakan. 


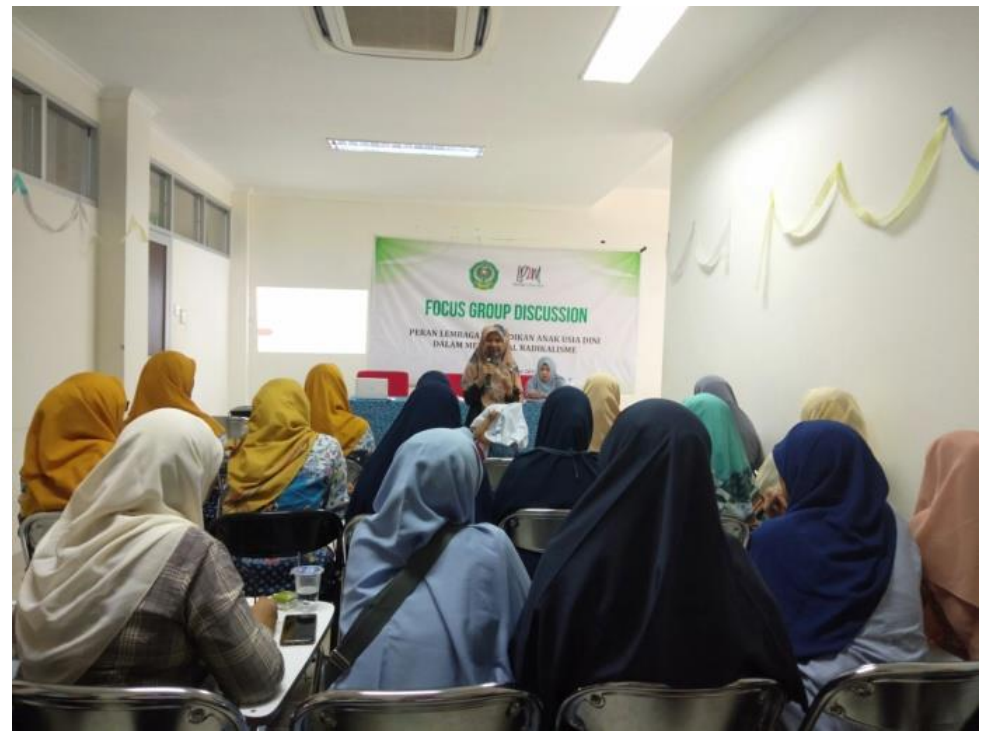

Gambar 3. Kegiatan Focus Group Discussion dengan Guru dan kepala Sekolah Lembaga PAUD

\section{Pemilihan Buku Ajar secara Selektif}

Lembaga PAUD menjadi sasaran empuk penjualan buku-buku aktivitas anak usia dini yang marak di pasaran. Selain bersumber dari tenaga pendidik, pintu masuk radikalisme adalah melalui buku ajar. Kenyataan ini disadari oleh pimpinan lembaga sebagai pemegang keputusan, dikarenakan dari 5 lembaga terdapat 4 lembaga yang melakukan proses seleksi dalam pemilihan bahan dan buku ajar berupa Lembar Kerja Anak (LKA)

Beberapa komponen yang diperhatikan dalam pemilihan bahan ajar yang akan dipilih terdiri dari: (1) kesesuaian dengan kurikulum PAUD, (2) kelengkapan materi dan (3) harga produk. Pertimbangan dalam penentuan bahan ajar tidak secara spesifik mempertimbangkan apakah buku ajar memiliki konten radikal. Namun melalui checklist analisa konten radikal pada buku ajar diperoleh kesimpulan semua buku yang digunakan bebas dari paparan ujaran kebencian pada golongan lain.

Seleksi buku ajar pada PAUD dilakukan untuk menghindari adanya sejumlah diksi (pilihan kata) yang memberikan nuansa radikalisme dalam buku-buku pelajaran taman kanak-kanak maupun SD yang memengaruhi pemaha- man dan sikap anak, dapat melekat seumur hidup. Pengaturan dilakukan oleh Kementerian Pendidikan dan Kebudayaan melalui Surat Edaran Nomor 109/CC2/DU/2016 yang berisi larangan bahan ajar PAUD yang mengandung kekerasan. (Anggraini, 2016)

Untuk itu hal hal yang patut diperhatikan dalam pemilihan buku ajar PAUD salah satunya adalah memeriksa latar belakang setiap penulis untuk melihat apakah memang ada orientasi tertentu yang mengarahkan tulisan-tulisan yang dianggap mengandung unsur kekerasan. Langkah lain adalah membaca secara menyeluruh isi buku ajar yang akan dipilih.

Upaya untuk menelaah secara keseluruhan isi sebuah lembar kerja anak telah dilakukan oleh 2 dari 5 lembaga. Menurut mereka komponen kesesuaian dengan kurikulum pmemaksa mereka untuk melakukan pemeriksaan menyeluruh sehingga dilakukan pengecekan dengan membaca seluruh isi lembar kerja anak yang akan dipilih.

Dari sekian buku yang pilih lembaga sampel terdapat satu sampel buku yang didalamnya mengandung diksi yang tidak dapat dikatakan radikal namun akan memberikan pengaruh dalam persepsi konseptual. Pada lembar kerja anak terdapat satu pertanyaan konsep berpakaian sopan, dimana digambarkan dua contoh penampilan yakni anak perempuan berjilbab dan anak perempun tanpa jilbab namun menggunakan kaos lengan pendek dan celana panjang. Anak diminta untuk memberikan tanda $(X)$ pada konsep berpakaian yang tidak sopan dan tanda $(\mathrm{V})$ pada gambar dengan pakaian ya sopan. 
Konsep sopan dalam berpakaian dalam bingkai masyarakat majemuk di Indonesia tidak dapat dirujuk dari salah satu agama mayoritas saja. Batasan sesuai norma sosial yang berlaku menjadi acuan. Sehingga penyuguhan gambar yang menggiring anak untuk memilih secara otomatis konsep berpakaian sopan dengan merujuk agama mayoritas akan menimbulkan persepsi konseptual bahwa tata cara berpakain yang tidak sesuai penggambaran ideal agama islam menjadi tidak sopan dimata anak anak.

Berkembangnya persepsi yang seperti ini akan menimbulkan sikap intoleran pada anak usia dini. pendidikan yang memunculkan sikap intoleran dalam melahirkan benih benih ekstrimisme yang mendorong sikap radikal (Pramudya \& Kartika Sari, 2019). Sikap tidak toleran merupakan satu dari empat karakter radikal (Khoiriyah, 2019).

Kepala sekolah dalam penyelenggaran PAUD berpegang teguh pada permendikbud 137 Tahun 2014 tentang standar nasional PAUD Sementera dalam proses pembelajaran mengacu pada permendikbud 146 tahun 2014 tentang kurikulum PAUD. Pengaturan yang dilakukan oleh pemerintah dianggap cukup jelas menurut kepala lembaga, namun menurut salah satu lembaga dibutuhkan pengaturan praktis berupa pedoman atau modul untuk penyelenggaraan PAUD anti Radikalisme.

\section{Pengenalan Kebhinekaan pada Anak Usia Dini}

Kenyataan bahwa Raudlatul Athfal (RA) adalah lembaga PAUD yang berada dalam sebuah naungan yayasan berbasis agama islam disadari betul oleh para orangtua. Umumnya faktor ini menjadi salah satu pertimbangan orangtua muslim dalam memilihkan sekolah untuk anak usia dini mereka.

Fakta menarik pernah terjadi pada salah satu lembaga sampel, dimana pernah sekali mereka menerima anak didik non muslim. Kejadian ini menarik karena orangtua muslim memasukkan anak dalam sekolah non muslim cukup banyak kasus terjadi namun sebaliknya orangtua non muslim memasukkan anak ke dalam sekolan muslim sangat jarang terjadi.

Penerimaan terhadap umat beragama lain untuk satu frame dalam pembelajaran anak usia dini menjadi contoh konkrit untuk pengenalan kebhinekaan pada anak usia dini. Pembelajaran anak usia dini melalui pendekatan tematik memunculkan salah satu tema 'Tanah Airku". Pembahasan pada tema ini sangat erat kaitannya dengan pengenalan identitas kebangsaan dan budaya bangsa yang beraneka ragam. Secara umum jika dilihat dari input anak didik terdapat 2 lembaga yang menyatakan bahwa orangtua anak didik mereka sangat beraneka ragam baik secara suku ras maupun latar belakang ekonomi. Sekolah dengan lingkungan sekitar berupa pendatang memungkinkan keanekaragaman. Dalam buku Ajar yang dipilih masing-masing lembaga sampel menunjukkan pemilihan yang sudah sesuai dalam pengenalan kebhinekaan.

Pemahaman keberagaman dapat dilakukan dengan berbagai cara, salah satunya melalui pendidikan. Keberagaman atau Multikulturalisme inilah yang menjadikan Indonesia memegang teguh kebhinekaan. Adanya multi etnis dan multi budaya menjadikan pendidikan multikultaral penting untuk diterapkan di Indonesia, sehingga masyarakat yang terdiri dari berbagai etnis yang berbeda hidup berdampingan tanpa menimbulkan konflik (Kusumaningrum \& Wahyono, 2019). Konteks pengenalan budaya yang beragam ini pada level pendidikan anak usia dini sangat penting untuk ditanamkan.

Mengenalkan kebhinekaan pada anak Usia dini dapat dijadikan upaya untuk pencegahan radikalisme. Mengajarkan anak untuk melakukan penerimaan diri bahwa Indonesia itu beragam agama dan suku bangsa. Sikap menghargai suku lain ditanamkan pada anak. Pola pendidikan seperti ini dapat dikatakan sebagai penanaman pendidikan multicultural yang bertujuan untuk menanamkan nilai nilai indentitas nasional (Rohman \& Ningsih, 2018) 
Bentuk konkrit kegiatan pengenalan kebhinekaan diselenggarakan dalam peringatan hari besar nasional. Anak usia dini dikenalkan dengan budaya dan tata cara berpakaian serta adat istiadat suku lain melalui parade budaya nasional atau karnaval.

\section{Sinergitas Lembaga dengan Orangtua dalam kegiatan parenting}

Bentuk upaya lain dalam pencegahan radikalisme dipaparkan oleh kepala sekolah adalah melalui kerjasama yang sinergis dengan orangtua. Pelaksanaan kegiatan parenting pada lembaga anak usia dini masih menjadi langkah efektif untuk mensinkronkan pembelajaran di sekolah dan di rumah.

Sebanyak 3 dari 5 lembaga sampel melakukan kegiatan parenting secara rutin dan terjadwal. Sisa lembaga lainnya melakukan kegiatan parenting secara incidental. Beberapa hal dalam pelaksanaan kegiatan parenting yang patut diperhatikan berdasarkan hasil wawancara dengan kepala sekolah antara lain adalah pemilihan narasumber dan materi serta kegiatan yang akan disampaikan.

Narasumber dalam kegiatan pertemuan orang tua akan memberikan pengaruh terhadap konsep berpikir orangtua anak usia dini. Sama halnya dengan penulis buku ajar, narasumber parenting juga patut diwaspadai sehingga perlu diseleksi apakah pembicara yang akan mengisi kegiatan sesuai dengan disiplin ilmu anak usia dini. Pertimbangan lain selain kualifikasi adalah kemungkinan adanya kepentingan pribadi untuk memasukkan paham tertentu. Dua hal ini patut dijadikan catatan oleh pimpinan lembaga dalam penetapan narasumber.

Lingkungan yang baik akan mempengaruhi perilaku anak. Karena anak dalam berinteraksi memerlukan perilaku yang positif supaya mendapatkan hal yang positif. Sebagai orang tua atau orang dewasa bagi anak-anak, kita harus menjadi model utama untuk anak- anak (Rizqiyani \& Asmodilasti, 2020). Apabila orangtua mendapatkan contoh perilaku yang salah dari kegiatan parenting dengan narasumber yang melakukan doktrinasi radikalisme maka akan berpengaruh terhadap sikap orangtua yang menjadi contoh bagi anak anak. Hal inilah yang menyebabkan pentingnya pemilihan narasumber dalam kegiatan parenting.

Selain bersumber dari luar pencegahan radikalisme melalui kegiatan parenting dapat dilakukan dengan penetapan materi yang lebih fokus terhadap perkembangan anak. Materi materi yang bersifat fanatisme keagamaan berlebih harus dihindari. Terbukti beberapa lembaga yang mengadakan kegiatan ini menyatakan materi umum yang sering disampaikan biasanya terkait dengan aspek perkembangan anak dan upaya stimulasi perkembangan anak.

Individu yang memiliki sikap toleran dan mampu menghargai orang orang lain tidak datang secara mendadak. Proses pemerolehan sikap ini harus dipupuk sejak dini. Gaya pengasuhan orang tua akan sangat berpengaruh terhadap sikap anak. Pembentukan sikap itu harus dilakukan sejak dini, pembiasaan yang dilakukan oleh orang yang terlibat dalam pengasuhan anak akan mempengaruhi karakter anak di kemudian hari. Perkembangan karakter inilah yang akan mempengaruhi bagaimana anak bersikap, bagaimana kemudian dia akan berinteraksi dengan lingkungannya (Arifiyanti, 2019). Disinilah letak urgensi kegiatan parenting yang dilakukan oleh lembaga, sebagai bekal bagi orangtua untuk pengambilan gaya pengasuhan yang tepat sesuai dengan keberagamanan yang ada serta tantangan zaman yang dihadapi.

Revolusi Industri yang membawa perkembangan teknologi banyak sedikit sangat berpengaruh terhadap pengasuhan orang tua serta perkembangan anak. Kehidupan yang serba open access memudahkan masyarakat untuk mendapatkan informasi. Kemungkinan anak anak memperoleh konten radikal secara online tidak dapat dibantahkan lagi. Demikian juga kemungkinan orangtua anak usia dini memperoleh kabar hoax atau konten radikalisme pun tidak terelakkan. Untuk itu dalam kegiatan parenting perlu diingatkan pentingnya pengawasan anak dalam penggunaan gadget dan seleksi informasi digital. Ancaman media 
online saat ini tidak hanya pornografi dan kekerasan, berbagai jejaring di ruang terbuka media sosial yang menyajikan contoh-contoh cara berpikir dan merespon berbagai situasi dengan sikap reaktif dan emosional saat ini juga menjadi ancaman baru bagi tumbuh kembang anak (Hendriani, 2017)

\section{Upaya Guru dalam desain Pembelajaran Anti Radikalisme}

Gambaran kegiatan pembelajaran pada sekolah PAUD yang dijadikan sampel penelitian diperoleh melalui kegiatan observasi, dimana peneliti membuat checklist lembar observasi dengan beberapa item yang akan diamati. Berikut komponen yang diamati dalam observasi kegiatan pembelajaran.

Tabel 1. Komponen Observasi Pembelajaran

\begin{tabular}{ll}
\hline No & Komponen Penciri Radikalisme \\
\hline 1. & Suasana belajar eksklusif \\
2. & Munculnya diksi ujaran kebencian oleh guru \\
3. & $\begin{array}{l}\text { Pengembangan kreasi tepuk dan lagu anak yang } \\
\text { memunculkan fanatisme agama berlebih }\end{array}$ \\
4. & Guru menggunakan simbol yang mencirikan radikal \\
\hline
\end{tabular}

Pelaksanaan obervasi dilakukan terhadap 5 lembaga, diperoleh data sebagai berikut; pertama; suasana pembelajaran tidak eksklusif, lembaga penelitian ini menerima beraneka ragama anak didik dari segala background bahkan lokasi kegiatan pembelajaran pun menyatu dengan masyarakat pada umumnya. Kedua, dari pengamatan lapangan tidak menunjukkan adanya doktrinasi serta ujaran kebencian terhadap agama lain ataupun suku tertentu. Namun berdasarkan hasil wawancara beberapa guru tidak memungkiri pernah melakukan pengucapan kalimat yang mengandung ketidaksenangan terhadap ajaran agama tertentu. Ketiga, berdasarkan hasil pengamatan tidak muncul adanya pengembangan kreasi tepuk dan lagu anak yang mengandung unsur fanatisme berlebih atau ujaran kebencian. Data ini didukung dengan hasil wawancara guru yang salah satunya menyepakati ketidaksetujuannya terhadap pengembangan "Tepuk Anak Sholeh" yang disertai tambahan ujaran kebencian seperti kalimat : Islam Islam YES, Kafir Kafir NO. konsep berpikir anak yang logis belum mampu memahami konsep abstrak seperti kata 'Kafir" sehingga menurut beberapa guru tidak diperlukan tambahan hal tersebut apabila dilakukan hanya akan menimbulkan persepsi yang berbeda pada anak. Kesalahan persepsi ini dalam memicu perilaku intoleran pada anak usia dini.

Keempat, berdasarkan pengamatan terdapat salah satu guru pada lembaga yang diteliti yang menggunakan simbolik ketaatan beragama. Salah satu guru menggunakan cadar dan dalam proses pembelajaran pun mengenakan cadar. Kondisi ini menjadi menarik karena guru tersebut berdasarkan konfirmasi melalui hasil wawancara dengan rekan sejawat, tidak pernah melakukan upaya penanaman fanatisme berlebihan. Fakta bahwa ada hal yang berbeda dari guru tersebut namun guru lain melakukan penerimaan dan berteman saling rukun menjadi satu contoh nyata adanya keberagaman dalam negeri ini. Catatan pentingnya terkait kondisi ini adalah anak belajar menirukan sikap toleran dari contoh nyata.

\section{Mendidik Karakter dengan Karakter}

Penggalian data berkaitan dengan desain pembelajaran yang dirancang oleh guru dalam rangka pencegahan radikalisme dilakukan melalui kegiatan wawancara dengan guru. Komponen yang dijadikan fokus dalam kegiatan ini adalah konsep pendidikan yang bagaimana agar radikalisme dapat dicegah dan langkah yang sudah pernah dilakukan dalam upaya melakukan pembelajaran anti radikalisme.

Hasil wawancara bersama dengan guru-guru yang berasal dari 5 lembaga yang diteliti menunjukkan bahwa untuk mencegah radikalisme pada anak usia dini harus melalui 
DOI: 10.31004/obsesi.v5i1.503

pendidikan yang fokus pada penanaman karakter. Kutipan wawancara dengan salah satu guru yang menunjukkan pentingnya penanaman karakter adalah sebagai berikut:

Kita berada dalam satu agama yang sama yaitu islam, kita sebagai guru mengajarkan pada anak bahwa islam itu agama yang cinta kedamaian. Cara yang tepat melakukannya yakni melalui mendidik anak dengan cinta. Sentuh kalbu anak didik kita penuhi dengan kasih sayang sehingga anak akan dapat saling menyayangi orang lain. Anak itu mudah meniru maka untuk menanamkan karakter harus dengan implementasi karakter tersebut. Guru memberikan teladan untuk contoh nyata yang dapat dilihat langsung anak usia dini (catatan wawancara dengan guru).

Semua guru yang terlibat dalam wawancara ini setuju bahwa untuk mendidik karakter harus dengan karakter. memberikan pengalaman nyata dan contoh teladan yang baik menjadi lebih efektif. Ujaran dan ajakan untuk saling mengasihi sesama dapat didesain dalam kegiatan yang mencontohkan implementasi kegiatan tersebut. Salah satu lembaga menyatakan bahwa anak-anak dilibatkan dalam satu kegiatan rutin bakti sosial yang diagendakan sekolah. Kegiatan ini memberi peluang anak untuk praktek langsung dalam hal mengasihi sesama tanpa memandang perbedaan di antara mereka.

Konsep mendidik karakter dengan karakter ini berkesesuaian dengan pandangan pandangan Dorothy Law Nolte yang menyatakan bahwa anak belajar dari kehidupannya. Beberapa pandangannya antara lain menyatakan bahwa "Jika anak dibesarkan dengan celaan maka anak akan belajar memaki dan jika anak dibesarkan dengan kebajikan dan tenggang rasa maka ia akan belajar menghormati (Nolte \& Harris, 2016).

Sifat anak yang mudah melakukan imitasi menjadikan kewaspadaan bagi orangorang yang terlibat dalam pengasuhannya, baik orang tua ataupun guru. Penanaman pendidikan karakter bagi anak usia dini dapat dilakukan dengan beragam cara bisa melalui dongeng seperti pada cerita fabel yang mengandung hikmah sikap mulia yang patut dicontoh. Namun karakter dikatakan sebagai akumulasi kebiasaan yang dilakukan oleh seseorang sehingga memiliki kesadaran diri (Juanda, 2019). Pembiasaan ini akan lebih efektif apabila dilakukan dengan contoh konkrit baik oleh guru maupun orangtua, maka untuk mengajarkan pendidikan karakter dapat dilakukan dengan mencontohkan karakter yang hendak diajarkan atau dibiasakan. Untuk itulah pentingnya mendidik karakter dengan karakter.

\section{Mengajarkan Kebhinekaan dengan Bermain Peran}

Menggambarkan keanekaragaman atau konsep kebhinekaan pada anak usia dini dapat dilakukan dengan kegiatan bermain. Dunia anak yang erat dengan permainan tidak dapat dihindari maka cara mudah untuk menanamkan karakter selain melalui teladan karakter adalah melalui bermain.

Pemerolehan data wawancara dengan guru terkait desain permainan yang seperti apa yang dapat digunakan untuk pencegahan radikalisme menunjukkan bahwa bermain peran adalah satunya. Fase perkembangan anak yang pada tahap di mana mereka mudah untuk melakukan imitasi dan senang dengan imajinasi dapat dijadikan modal dasar untuk melakukan kegiatan role play.

Tiga dari lima lembaga PAUD yang diteliti menyatakan pernah mensimulasikan bermain peran dengan beraneka ragam peran dari suku yang berbeda. Kegiatan bermain peran sangat disukai oleh anak usia dini, dengan bermain peran mereka dapat berpura pura menjadi orang lain.

Kegiatan bermain peran efektif dalam penananam kebhinekaan pada anak usia dini. memposisikan aneka ragam budaya dalam satu frame menjadikan anak mengenali macammacam budaya bangsa sendiri. Kegiatan bermain peran yang sudah dilakukan selama ini masih terfokus pada mensejajarkan adanya beraneka ragam budaya di Indonesia. Belum 
pernah ada lembaga PAUD yang berupaya mensimulasikan bermain peran dengan mengexpose hal hal sensitif seperti adanya perbedaan minoritas dan mayoritas.

Simulasi bermain peran dengan mempraktekkan langsung adanya kenyataan minoritas dan mayoritas akan memberikan pengalaman langsung pada anak. Anak dengan peran minoritas akan merasakan bagaimana diperlakuan sebagai kaum marginal. Pesan moral dalam permainan peran ini adalah anti diskriminasi. Sikap diskriminatif erat kaitannya dengan intoleransi sehingga akan memicu radikalisme. Dengan adanya praktek bermain peran seperti ini harapannya anak akan memperoleh pemahaman bahwa sikap tidak menghargai itu menyakitkan bagi orang lain yang tidak dihargainya

\section{SIMPULAN}

Strategi pencegahan radikalisme yang dilakukan oleh kepala lembaga PAUD diantaranya (1) Mengidentifikasi keterpaparan radikalisme pada saat proses seleksi rekrutmen guru, (2) melakukan pemilihan bahan ajar seperti buku atau Lembar Kerja Anak (LKA) secara selektif (3) Pengenalan Kebhinekaan pada anak (4) Melakukan sinergi dengan orangtua dalam kegiatan parenting. Sementara guru melakukan upaya pencegahan dengan penanaman pendidikan karakter melalui karakter (teladan guru) dan mensimulasikan kebhinekaan dalam permainan peran. Penelitian ini tidak sampai pada penyusunan kurikulum anti radikalisme atau penyusunan modul pembelajaran PAUD berbasis kebhinekaan, semoga dapat dijadikan peluang untuk penelitian selanjutnya.

\section{UCAPAN TERIMAKASIH}

Penulis secara langsung mengucapkan terimakasih kepada semua pihak yang telah membantu dalam kegiatan penelitian ini. Secara khusus penulis mengucapkan terimakasih kepada Ketua Ikatan Guru Raudlatul Athfal (IGRA) Kabupaten Cirebon, Jawa Barat yang telah banyak membantu pelaksanaan penelitian. Ucapan terimakasih penulis sampaikan kepada IAIN Syekh Nurjati Cirebon yang telah memberikan dukungan berupa dana dan fasilitas dalam kegiatan penelitian. Penelitian ini dibiayai oleh DIPA IAIN Syekh Nurjati Cirebon Tahun 2019

\section{DAFTAR PUSTAKA}

Abdillah, D. S., Muhammad, A. R., Ulya, A., Sodali, H. A., \& Choiriya, D. D. (2018). DeRadikalisasi Anak dan Remaja dengan Meningkatkan Nasionalisme dan Spiritualitas Melalui Program Pembelajaran Anak Negeri. Berdikari: Jurnal Pengabdian Masyarakat Indonesia, 1(1), 27-34. https:// doi.org/10.11594/bjtls.01.01.04

Alexandra, F. (2017). Analisis Kajian Terorisme dan Radikalisme dalam 3 Perspektif Teoritis. Jurnal Paradigma, 6(3), 137-146.

Anggraini, S. (2016). Budaya Literasi Dalam Komunikasi. Wacana, XV(3), 181-279. Retrieved from http://journal.moestopo.ac.id/index.php/wacana/article/viewFile/51/29

Arifiyanti, N. (2019). Relationship between Authoritative Parenting Style and Preschools Prosocial Behavior. Jurnal Obsesi: Jurnal Pendidikan Anak Usia Dini, 3(2), 311. https:// doi.org/10.31004/obsesi.v3i2.166

BBC News Indonesia. (2018). Pawai murid TK bercadar dan bawa replika senjata, 'isyarat ancaman radikalisme mulai mengakar. Retrieved April 20, 2020, from BBC News Indonesia website: https:// www.bbc.com/indonesia/indonesia-45248639

Hendriani, W. (2017). Menumbuhkan Online Resilience pada Anak di Era Teknologi Digital. Prosiding Temu Ilmiah X Ikatan Psikologi Perkembangan Indonesia, 52-58.

Imron, A. (2018). Penguatan Islam Moderat melalui Metode Pembelajaran Demokrasi di Madrasah Ibtidaiyah. Edukasia Islamika, 3(1), 1. https://doi.org/10.28918/jei.v3i1.1675

Joni. (2015). Pembelajaran Tematik Pada Anak Usia dini. Idea Nursing Journal, 3(1), 35-49. 
DOI: 10.31004/obsesi.v5i1.503

Juanda, J. (2019). Pendidikan Karakter Anak Usia Dini melalui Sastra Klasik Fabel Versi Daring. Jurnal Obsesi: Jurnal Pendidikan Anak Usia Dini, 3(1), 39. https://doi.org/10.31004/obsesi.v3i1.126

Khamid, N. (2016). Bahaya Radikalisme terhadap NKRI. Millati: Journal of Islamic Studies and Humanities, 1(1), 123. https:/ / doi.org/10.18326/mlt.v1i1.123-152

Khoiriyah, K. (2019). Pendidikan Anti Radikalisme dan Strategi Menggahadapinya (Ikhtiar Menyusutkan Gerakan Radikalisme di Indonesia. Tarbiyatuna: Kajian Pendidikan Islam, 3(2), 122. https://doi.org/10.29062/tarbiyatuna.v3i2.263

Kusumaningrum, K., \& Wahyono, S. B. (2019). Developing A Pop-Up Storybook Based on Multicultural Education for Early Childhood Students. Jurnal Obsesi : Jurnal Pendidikan Anak Usia Dini, 4(1), 41. https:// doi.org/10.31004/obsesi.v4i1.230

Muchith, M. S. (2016). Radikalisme dalam Dunia Pendidikan. ADDIN, 10(1), 163. https://doi.org/10.21043/addin.v10i1.1133

Nolte, D. L., \& Harris, R. (2016). Anak Anak Belajar dari Kehidupannya Nilai Nilai Parenting Klasik Dunia. Yogyakarta: Pustaka Pelajar.

Nurfitriana. (2018). Pendidikan Anak Usia Dini dalam Al-Qur'an. 103-119.

Permendikbud No 137. Permendikbud 137 Tahun 2014. , (2014).

Pramudya, D. U., \& Kartika Sari, M. M. (2019). Mekanisme Sekolah Rakyat Bhineka (SRB) dalam Menanamkan Nilai-Nilai Kebhinekaan pada Anak-Anak di Lidah Kulon Surabaya. Kajian Moral Dan Kewarganeraan, 07(02), 708-722.

Rizqiyani, R., \& Asmodilasti, A. (2020). Perilaku Prososial Anak Taman kanak-Kanak. Awlady: Jurnal Pendidikan Anak, 6(1). https:// doi.org/10.24235/awlady.v6i1.4189

Rohman, A., \& Ningsih, Y. E. (2018). Pendidikan Multikultural : Penguatan Identitas Nasional Di Era Revolusi Industri 4.0. UNWAHA Jombang, 1(September), 44-50. Retrieved from http://ejournal.unwaha.ac.id/index.php/snami/article/view/261

Rokhmad, A. (2012). Radikalisme Islam dan Upaya Deradikalisasi Paham Radikal. Walisongo: Jurnal Penelitian Sosial Keagamaan, 20(1), 79. https:// doi.org/10.21580/ws.20.1.185

Shobihah, I. F. (2018). Menangkal Potensi Radikalisme Sejak Dini Melalui Penyelenggaraan Bimbingan Konseling Dalam Pendidikan Tingkat Dasar. Atthiflah: Journal of Early Childhood Islamic Education, 5(9), 1-10. https://doi.org/10.1017/CBO9781107415324.004

Sihombing, J. M. (2005). Kekerasan Terhadap Masyarakat Marginal. Yogyakarta: Penerbit Narasi.

Umro, J., Stit, D., \& Pasuruan, P. (2017). Upaya Guru Pendidikan Agama Islam dalam Mencegah Radikalisme Agama di Sekolah. Journal Of Islamic Education (JIE), II(1), 89108.

Wahid, Y. (2017). 11 Juta Warga Siap Lakukan Tindakan radikal. Retrieved April 20, 2020, from Tempo website: https://nasional.tempo.co/read/847391/yenny-wahid-11-jutawarga-siap-lakukan-tindakan-radikal

Wahyudi, D., \& Kurniasih, N. (2018). Konstruksi Pendidikan Keluarga sebagai Pionir Deradikalisasi Paham Agama. FIKRI: Jurnal Kajian Agama, Sosial Dan Budaya, 3(2), 325. https:// doi.org/10.25217/jf.v3i2.365 